\title{
The leopard-skin of Heracles: traditional wisdom and untraditional madness in a Ghanaian Alcestis
}

Book or Report Section

Accepted Version

Goff, B. (2016) The leopard-skin of Heracles: traditional wisdom and untraditional madness in a Ghanaian Alcestis. In: Kyriakou, P. and Rengakos, A. (eds.) Wisdom and Folly in Euripides. Trends in Classics - Supplementary Volumes 31. De Gruyter, pp. 347-364. ISBN 9783110452259 Available at http://centaur.reading.ac.uk/54466/

It is advisable to refer to the publisher's version if you intend to cite from the work. See Guidance on citing.

Publisher: De Gruyter

All outputs in CentAUR are protected by Intellectual Property Rights law, including copyright law. Copyright and IPR is retained by the creators or other copyright holders. Terms and conditions for use of this material are defined in 
the End User Agreement.

www.reading.ac.uk/centaur

\section{CentAUR}

Central Archive at the University of Reading

Reading's research outputs online 
The Leopard-skin of Heracles: traditional wisdom and untraditional madness in a

Ghanaian Alcestis.

Barbara Goff

Euripidean drama characteristically questions human abilities in the face of terrible odds, undermining any simple faith in human solutions even while - sometimes - valuing human sympathies. The notions of wisdom and folly come under close scrutiny, and in tragedy the stakes are unusually high; the misapplication of human ingenuity may result in death, and conversely human wisdom may need to be exercised in managing the realisation of mortality. Such a perspective resonates widely, but has fifth-century relevance in that it casts doubt on the ambitions of democratic politics, with their commitment to the largely human management of decision-making and the peaceful transfer of power. Many Euripidean dramas are particularly conscious of the developing fifth-century vocabulary of perception, deploying 'sophistic' terms such as synesis. ${ }^{1}$ Although some of this vocabulary is especially characteristic of later plays, the exploration of sophia and its cognates, and the representation of madness and other extreme mental states, is recognisable in plays of much earlier date. As intellectual activity is examined, the question whether it amounts to wisdom or instead to folly is repeatedly posed.

In Alcestis, the division between 'wisdom' and 'folly' is multiplied by the play's double generic affiliation, its provocative display of both tragic and comic elements, ${ }^{2}$ and by the way in which any moral judgement on the main characters seems to be provisional and suspended. Does Admetus ever gain a profound understanding of what has happened, of what he has done? Critics remain divided, apportioning both praise and blame to the protagonist and indeed to other characters. ${ }^{3}$ At 940 , speaking to the Chorus over the corpse 


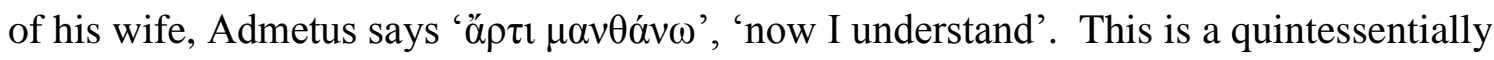
tragic utterance like ' $\tau$ í $\delta \rho \alpha ́ \sigma \omega ?$ ? 'what do I do? ${ }^{, 4}$ But uniquely among tragic protagonists Admetus does not have to understand, because he is exempt from his own death and, after the rescue by Heracles, does not have to face the loss of another.

In this essay I shall first consider the vocabulary of wisdom and folly in Alcestis, and its relation to the generic and moral doubling that I have noted. But the bulk of my discussion will be taken up with a play that is much less familiar, Edufa by the Ghanaian playwright Efua Sutherland. To all intents and purposes an adaptation of Alcestis, this play too is marked by generic ambivalence, moral doubt, and a discourse of wisdom and folly that is strongly conscious of tradition. Edufa is also, significantly, an adaptation of a Greek tragedy that was produced and published in the wake of Ghana's independence, so that its reservations about human capacities are available for specific political interpretation. Although most critics agree that it is modelled on Alcestis, ${ }^{5}$ there are significant variations in several scenes; we shall examine some of those that relate to the themes of wisdom and folly, but also those that speak to generic identity and the possibilities of moral judgement, praise and blame. Edufa is often typed as didactic, or even pedagogic, but I shall suggest that it follows Greek precedent in having more pointed political relevance.

There are only four uses of the word sophos in Alcestis, and there is no use of terms such as synesis. Each use of sophos is individually quite striking. The first instance comes in the scene between Apollo and Death, where Death chides Apollo for suggesting that he should wait until Alcestis is older before carrying her off, in order to get better grave goods. 'You propose laws for the rich' he points out (57), to which Apollo replies (58)

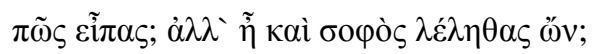


What are you saying? Have you secretly become clever?

The incongruous term, here abusively sarcastic, epitomises the slightly pantomimic quality of the scene. Arguably more significant is the use of the term at 348-9. Origa ${ }^{6}$ cites Snell (1924) for the claim that technical ability and craft is at the root of the word's significance, and it appears for the first time in Euripides with this kind of connotation, when Admetus says that he will employ the 'skilled hand' of craftsmen to make an image of Alcestis after her death, which will bring him some cold comfort:

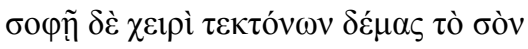

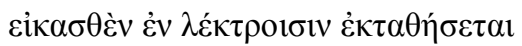

by the wise hand of craftsmen your body

represented will be laid out on the bed. ${ }^{7}$

The 'fifth-century' term might be thought of as highly appropriate here, in that human ingenuity is going to do its best to overcome death, by the use of the image. ${ }^{8}$ But Stieber

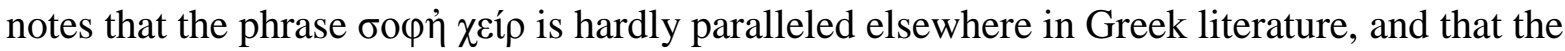
combination of 'wise' and 'hand' is 'striking, if not jarring, especially in the age of the Sophists'. ${ }^{9}$ Admetus' overall plan for Alcestis' commemoration has thoroughly divided critics, who have found it grotesque as well as idealistic. ${ }^{10}$ So the challenging use of sophos here is duplicated by the discomfiting nature of Admetus' proposal. The image of Alcestis which the 'wise hand' will construct is, arguably, made visible in the silent figure who closes the play, and who provokes so many varied interpretations, so that the means of overcoming death is questionable twice over. ${ }^{11}$ This particular use of sophos, in a context of creative activity, also points to the play itself, and almost seems to foresee the critical ambivalence that surrounds its experimentation. 
There is a similar discomfort around the other uses of the word, for instance at 699 when Pheres accuses Admetus of wisely, or cleverly, finding a method of putting off death for ever, by getting successive wives to die for him. Origa ${ }^{12}$ suggests that sophos in this kind of context, where its connotations are so negative, is equivalent to kakos, indicating a lack of scruple; and here it underlines an indictment of Admetus that many critics share. At 779 Heracles encourages the Servant not to mourn the 'foreign' woman but to become sophōteros by listening to his sage advice. He proceeds, tipsily, to deliver a collection of hoary saws about the uncertainty of life and the necessity to enjoy the moment (780-802). Throughout this embarrassing speech he draws on a fifth-century and even sophistic vocabulary including tyche, techne, didaskein, logos, physis, and phroneo, but none of these words succeeds in making him look at all intelligent, and it seems as if his attempt at sophia has thoroughly misfired. And when he discovers that the 'foreign' woman is in fact Alcestis, he quickly sobers up. For all this, however, his diatribe does have close affinities to many tragic consolations that are delivered 'straight', so that the line between wise and foolish seems not very hard to cross.

There are also a few loaded moments when words for foolishness are deployed. The minute that Admetus has ushered Heracles into the house, the Chorus rounds on him and asks him (along with the audience, we might imagine) 'What are you doing? ...Why are you foolish ( $\left.\mu \tilde{\omega} \rho \varsigma_{\varsigma}\right)$ ?' (552). This outburst seems to show the Chorus horrified at Admetus' lack of common sense. Yet a few lines later the Chorus praises Admetus's sophia (602) and proclaims, if I may over-simplify a complex utterance, that good people always get things right. $^{13}$

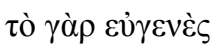

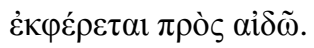




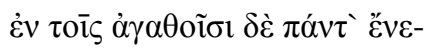

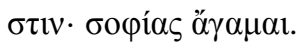

Good birth

Is borne away towards respect.

In good people is everything;

I love [his] wisdom.

The punctuation of this passage is not certain, as much of the transmission offers a full stop

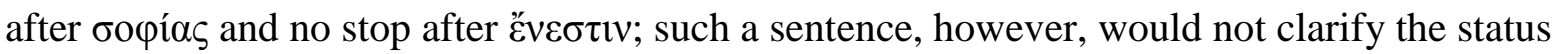
of Admetus's wisdom here at all, and modern editors including Parker and Diggle punctuate as above. ${ }^{14}$ At 728 , in another difficult moment, Pheres calls Alcestis aphrona, without thought or senseless. Admetus has just exclaimed 'Oh, oh, how full of shamelessness is old age' and Pheres rejoins 'She was not shameless; but you found her foolish' (727-8). This is not a final hostile judgement on her, instead forming part of the escalating aggression between him and his son, but it repeats the unsettling effect that the other words for wisdom or foolishness have had. ${ }^{15}$ We might also include Heracles in a discourse of 'folly', because he is clearly impaired by partying when he comes on stage to berate the Servant. When he switches out of this into the valiant speech at 837-60, proclaiming the necessity to battle even Death, he compounds the difficulty of discerning the emotional tone of the play as a whole.

A focus on wisdom and folly in the Alcestis, then, indicates and contributes to the split that criticism has repeatedly found in the play, whereby its different elements decline to cohere into a stable judgment on Admetus or indeed any other character. Admetus is 
represented in the criticism as villainous as well as noble, and he is either irredeemably myopic where the worth of Alcestis is concerned, and thus incapable of recognising the significant elements of his situation, or he is indeed a good man who understands where priorities lie and is suitably rewarded. Similarly, critical views of Alcestis show her as tiresome as well as virtuous, and the play as a whole is perceived as dark and cynical or alternatively healing and uplifting. ${ }^{16}$ Not only are the judgements kept in solution during the drama, but other dualities are also in play; Alcestis participates in the genre of satyr drama as well as of tragedy, and Alcestis herself is dead as well as alive $(141,519,521)$. The double music in the house of which the Servant complains (760) is symptomatic. We should not be surprised to find wisdom and folly exerting pressure upon one another.

The Ghanaian Alcestis of my title similarly marshals some striking moments of wisdom and folly, and plays complexly with genre and with moral judgement. While many African adaptations of Greek tragedy have been the object of sustained critical reflection in recent years, ${ }^{17}$ Edufa has so far escaped much attention; those who have written about it have done so within the discipline of African literature rather than that of Classics. The play is now increasingly recognised as one of the 'Afro-Greek' plays, adaptations that mark independence and then the postcolonial period, ${ }^{18}$ but some of its distinctive characteristics are not always acknowledged. Produced in 1962, five years after independence, Edufa was published in 1967, one year after Nkrumah's overthrow, and is thus among the first of the 'Afro-Greek' plays. ${ }^{19}$ It is the earliest such adaptation to be written by a woman, and Efua Sutherland was not just any woman; she was a dauntless campaigner for independence on the cultural as well as the political front, and founder of many post-independence institutions. ${ }^{20}$ A further way in which Edufa is set apart from other Afro-Greek adaptations is that it does not tackle one of the mighty dramas of violent resistance and revenge, such as Bacchae or Medea or Antigone, which might be readily rewritten in such a way as to destabilise 
colonialist assumptions of cultural superiority, and thus might be congenial to an African dramatist. ${ }^{21}$ Instead, it situates itself in relation to a drama which is generically troubled to the extent of having an almost happy ending. As we shall see, Edufa pursues the Greek ending to a more troubled destination.

We might also note at this point that to adapt a Greek tragedy was perhaps an even more surprising move for Efua Sutherland than for other African playwrights. She was characteristically careful to make her work accessible to 'ordinary' Ghanaians, but adapting a Greek tragedy may have seemed to contradict this aim, not least in the unavoidable identification of Greek tragedy with western colonialism. Devoting her long career to building a theatre that would be worthy of the first African nation to achieve independence, Sutherland developed a range of forms and discourses that drew on Ghanaian oral traditions. She is perhaps best known for the play The Marriage of Anansewa, which invokes the 'Ananse' stories of West African folklore. The Alcestis may even have been attractive to her because it involves folk- or even fairy-tale like aspects. Perhaps because of this commitment to accessibility, her plays, including Edufa, have often been read in relatively straightforward terms as 'didactic' or 'pedagogic'. ${ }^{22}$ The discourse of wisdom and folly in this play has not been fully explored, or has been assimilated to a discourse on tradition and modernity, where the 'lesson' of the play is understood to be that Ghanaians should not be too quick to embrace the materialism and success that comes with westernisation. With the increasing focus on postcolonial literature, more sophisticated accounts have emerged, ${ }^{23}$ but the relationship between the Ghanaian identity of the play, and its invocation of a Greek tradition, has not attracted sustained attention. Yet given that 'westernisation' by European colonialism was what brought Greek tragedy to an African audience, we might want to investigate further the wisdom or folly of adopting the Greek tragic model. 
The eponymous Edufa, who is a prosperous westernised businessman and pillar of the community, has acquired a traditional African charm that will let him live if another dies for him, and almost accidentally has prevailed upon his wife Ampoma to agree to this. The dramatic date is the day when Ampoma must die, but Edufa intends to counter the power of the charm by combating it with traditional remedies, with the help of his sister Abena, the housekeeper Seguwa, and his 'idiot' servant Sam. These efforts render him distinct from Admetus, who can do nothing to halt the approach of Death, as does the Chorus of village women whom Edufa must keep ignorant of the household's plight. His friend Senchi, the Heracles-figure for whom he throws a party, is similarly kept in the dark, even though Ampoma is dying during the entertainment itself; nobody apart from the married couple understands what is happening to her until it is far too late. This is a tragic situation, but with a comic potential for misunderstanding which gives the play a generic instability similar to that which marks Alcestis. As in Alcestis, the inevitability of death puts all coping strategies into question, but unlike in Alcestis, no strategy, by human, divine, or by the drama itself, succeeds in rescuing Ampoma.

To the extent that 'wisdom' emerges into this play as a concern, it is often in relation to tradition or convention. In this respect the theme is closely tied to the Ghanaian context in which the events are set, and several elements of the play, such as its music, its religious practices and its folklore, are specifically Ghanaian. Edufa, the 'big man' of the town, has used a charm to save his life rather than a gift from the gods, and this provokes much discourse on traditional ritual practices between him and other characters, prominently his sister and his father. The Chorus, all women of the nearby town, come to Edufa's house not to commiserate on his wife's death, because she does not die until the last moments of the play, but to perform an established collective ritual of consolation, driving out evil from all the town's houses. They deliver themselves of time-worn sentiments not unlike those of the 
Chorus and Heracles in Alcestis. The Chorus in Alcestis attempt to 'console' Admetus by pointing out, tritely, that many other men have lost noble wives, (416-19, my translation):

Admetus, it is necessary for you to bear these disasters;

for you are not at all the first or last of humans

to lose a noble wife; know that

All of us are due to die.

Some of the pronouncements by the Chorus of Edufa also address this kind of shared suffering, and if Heracles enjoins cheerfulness in the face of inevitable change, Edufa's Chorus sounds not dissimilar:

To purge our house also in the same old manner, for calamity is for all mankind and none is free from woe. (119) 24

Crying the death day of another

is crying your own death day.

While we mourn for another

We mourn for ourselves.

One's death is the death of all mankind.

One of the Chorus-members sums up thus:

Tears and laughter. That's how it is. It isn't all tears and sorrow, my friends. Tears and laughter. It isn't all want and pain. With one hand we wipe away the unsweet water. And with the other we raise a cup of sweetness to our lips. It isn't all tears, my friends, this world of humankind. (121) 
The quotation on 'tears and laughter' may point towards the generic instability of both 'Alcestis' plays, as they divide repeatedly into the tragic and the comic.

Like Alcestis, Edufa stages a gruesome row between the protagonist and his father, and in this scene too we can see different models of traditional wisdom and untraditional folly. The confrontation between African tradition and westernisation is particularly acute here, and is framed in terms of different forms of knowledge and education; in contrast, there is hardly any discussion of the father's refusal to die for his son, which attracts considerable attention in Alcestis. In Edufa the father Kankam arrives much earlier on in the action than Pheres, and much more aggressively. He taps angrily on the ground with his umbrella when the housekeeper Seguwa is first reluctant to call his son, and shouts his name (107), whereas Pheres is ready to condole with his son, and it is Admetus who reacts with anger and rejects the familial relation (629-72). Kankam fell out with his son years ago over his materialist outlook, but returns to the house because he has discovered the story behind Ampoma's illness. From his own diviner, Kankam has acquired knowledge of Edufa's charm and its consequences, and he rehearses the events in detail, reminding Edufa of his various stratagems first to get the charm to work and then, when Ampoma unexpectedly took the death upon herself, to stop it (110-12). Kankam does not spend time defending his own decision not to die, but alternately reprimands his son and pleads with him to do more to save Ampoma's life. Accepting that Edufa was offered life in return for another's life, he goes on to say

Has that not been heard before? Has that not been said to many of us mortal men? Why were you not content, like all of us, to purge your soul by offering gifts of cola and white calico to the needy, and sacrificing a chicken or a sheep, or, since you can afford it, a cow? 
Here, the offer of a life for a life is interpreted as meaning simply the ordinary animal sacrifice that many men do and should make. Since Edufa has acquired Ampoma's life instead, however, Kankam urges him to a different ritual act (112):

Confess and denounce your wrong. Bring out that evil charm. And before Ampoma and all of us whose souls are corporate in this household, denounce it. Burn it.

It is not clear whether this is a traditional ritual or whether Kankam is improvising, but his reference to the whole household does tie his suggestion to established Ghanaian practice, in which the household is very significant. ${ }^{25}$

At first sight, it seems as if the play is dividing Edufa from Kankam on the grounds of traditional observances versus modernising materialism. Edufa is clearly a successful business man in a western mode; for instance, as the play develops we learn that he has made money from quarrying granite (132). But this is not sufficient as an interpretation of the play, because Edufa is using 'traditional' remedies against the charm already; he is collecting dew and river water to mix with herbs, and he has also sent his servant Sam to yet another diviner, who has provided counter charms and spells (128-9). Conversely, Kankam is not to be identified solely with 'traditional' wisdom, as Edufa makes clear. When Kankam prescribes the rituals, Edufa is scornful: 'Do you want me to take you seriously? You cannot believe all this, you who educated me to lift me to another plane of living' (109). The father who represents himself as a repository of traditional wisdom thus appears to have rejected it in favour of a westernised education for his son, which has rendered him 'emancipated' (109). Indeed, Edufa mentions the possibility of hiring western doctors to cure Ampoma, although in the end he does not do so: 'There are doctors with skill enough to sell for what's ailing her, and I can pay their fees' (112). So, Kankam enjoins traditional methods of defying death, but we cannot be sure that they will work, particularly since he has not always identified 
completely with traditional practices; Edufa, who has identified with more western methods of advancing his career and status, has been tripped up by the power of the charm, but is endeavouring to counteract it in traditional ways - which in the end will prove equally fruitless.

The play has, as I noted above, been typed as 'didactic' in the criticism, but it is hard to see exactly what it is didactic of. It seems to enjoin caution about westernisation, because it is the westernised Edufa who is brought down by the play, but the drama does not show a whole-hearted support of African tradition either; traditional wisdom does not 'work' in any straightforward way, and it is the 'traditional' charm which carries the seeds of destruction. Commentators note that Edufa can be criticised for not cleaving wholeheartedly either to 'tradition' or to western ways, but for rootlessly supposing that he can pick and choose among different cultures' resources, and indeed he says himself, after his father leaves, that he is condemned 'for my failure to create a faith... I bent my knee where I have no creed and I'm constrained for my mockery' (114-15). ${ }^{26}$ Yet the play itself is combining African and European, or at least Greek, in its dramatic allegiances. In at least one of Sutherland's other dramas a westernised future is considered a possible means of salvation from a stagnating past, so modernity can be represented as a source of success. ${ }^{27}$ We should also perhaps register that as with Admetus, moral judgements about Edufa can be divided. Although many critics find him unattractive in his worldliness, and condemn him, as I have said, for his failure to take seriously the charm which he nonetheless uses, he is admired by the community (98) and loved by otherwise admirable characters like his sister Abena, Ampoma, and Senchi.

Types of wisdom and education are at stake in the agon between Edufa and Kankam, but folly, or rather madness, is also a counter in their argument. Edufa goes so far as to call 
his father mad (111), an insult which contravenes all decorum. Kankam cries out 'Nyame above! To say father and call me mad! My ntoro with you shivers with the shock of it! (111). ${ }^{28}$ But Kankam then recuperates the insult: 'All right, stranger, I am mad! And madness is uncanny. Have you not noticed how many a time the mad seem to know things hidden from men in their right minds?' (111). This notion that the mad might be more sane than the sane is then legible in other parts of the play. In one quite puzzling scene, the servant Sam has been sent by Edufa to consult a diviner, and brings back what is meant to be the definitive way of coping with the charm. Sam is clearly intellectually impaired, and the scene offers some humour at his expense, but he also remarks repeatedly on how 'An idiot's life isn't so bad. There are always people to stop children throwing stones at us. They only do that for idiots, I find' $(127,128)$. He suggests that Edufa might want to come back as an 'idiot' when he is born again, and the play's ending does go some way towards that choice.

Ampoma is also described as wandering in her mind during the course of the play. Ampoma is, I would argue, far more central to the play's action than is Alcestis in her play, particularly since Ampoma is alive for most of the drama. ${ }^{29}$ When she appears at the party during which she will die - the stage directions prescribe that she is in 'a strange mood', and 'frequently talks like one whose mind is straying' (143). It is during this party that she makes an unconventional gesture which may be counted as a kind of 'folly'; she puts a string of her waist beads around Edufa's neck (146-47). Waist beads in Ghanaian culture are a crucial part of female identity; marking the stages of female life, and at puberty taking responsibility for the shape of the woman's body, they stay unseen, under the clothes, reserved for the gaze of the husband. ${ }^{30}$ While Ampoma's gesture lays claim to Edufa so that he does not marry another woman, it also expresses physical and sexual affection in an unusually public fashion, which causes confusion, amazement and astonishment among her audience (146-7). Edufa seems embarrassed, but his friend Senchi seems to think it is an impressive and 
wonderful gesture; critics have sometimes interpreted it in very negative ways. ${ }^{31}$ Aware of the outrageous nature of her act, mentioning her accustomed modesty and shame (146), Ampoma seems to play with cultural expectations even while she is acting out the role of the loyal and self-sacrificing wife. ${ }^{32}$ The gesture may also invite us to imagine the entrance of another woman in Edufa, as in Alcestis, but in fact Edufa will never be faced with any such dilemma.

A different kind of folly, or madness, can be read in the scenes which feature Senchi, the friend of Edufa who occupies the Heracles-position. Senchi is not in the least like Heracles in his strength or ability to defeat death; at the moment when Ampoma dies Senchi is left outside the house helpless, not unlike many a Greek chorus in similar trying circumstances, and he can effect no rescue. But he reproduces elements of the Heracles from Alcestis in his love of partying and of women, which dominate several of the scenes; and he also provides the most comic moments in the play, as does Heracles in Alcestis. Senchi is a 'fool' in a conventional sense too in that he does not have a regular job but makes a living by hawking songs; he is very poor, so that he has to borrow from Edufa clothes that are far too big for him, and ends up looking an 'ass' (133); he represents himself as rootless and insubstantial compared to the 'solidity' of Edufa (132). His life is the antithesis of Edufa's; instead of being grounded in business ventures and recognised respectability, he is on the road, in a shabby suit and with a battered suitcase $(122,132)$. Yet Senchi's 'folly' is not straightforward. It is he who brings Edufa to utter a version of ó $\rho \tau \imath \mu \alpha v \theta \alpha \dot{\alpha} \omega \omega$, 'I'm being compelled to learn', when he presses his host to name and explain his 'solid' and 'substantial' identity, and Edufa confesses that it is 'illusory' (132). Senchi never gets as drunk as Heracles, and although he is enjoying himself, he displays a developed social sense. The women of the Chorus have been invited to the house to dine, in order to celebrate what appears to be Ampoma's improved health; he entertains them, and sweeps everybody up into 
an impromptu dance (142). He writes a song for Ampoma, perhaps thus fulfilling the Greek chorus' prophecy that Alcestis would be praised in song.

Senchi has been dismissed in the criticism as variously shallow, hedonistic, and disillusioned, ${ }^{33}$ but we should arguably say more about this figure. For a start, he is a writer of songs, a creative artist, as he describes himself (141), and thus the nearest figure in the play to the playwright herself. If we pursue the theme of wisdom and folly, we find too that his speeches are often quite significant. From the moment he enters, he uses various discourses in a playful manner, satirising both the colonial occupiers and the architects of independence with their 'five-year plans'. When he enters, on seeing Edufa surrounded by all the women of the Chorus, his reaction is: 'What are you doing here? Practising polygamy? Or big-mammy: or what .... All good stock, by their looks. Local breed?' (122). The Chorus's other activities are also grist to his comic mill. When he hears that the women have been practising a condolence rite, he objects 'Why do you people prolong your sorrows so? Though, I must observe, you have a funny way of going about it, drinking and sniggering' (123). While he thus maintains a distance from traditional ritual activities, he also teases Edufa for his more westernised allegiances (122-23):

\footnotetext{
What are you practising now? Catholicism, spiritualism, neo-theosophy or what? Last time I passed through here, you were an intellectual atheist...I wouldn't be surprised to see you turned Buddhist monk next time.
}

At the party he declines to play the western game of Musical Chairs, because 'That being a little colonial is somewhat inappropriate here...' (140), and he mocks colonial anthropological discourse when he greets a Chorus member with the words 'May I hold your hand? Or is that considered adultery in these parts? I always try to get the local customs straight before I begin negotiations' (139). In other contexts, however, Senchi also riffs on 
the discourse of postcolonial reconstruction with its emphasis on five-year plans: 'Don't call it a party, woman. Call it something like Senchi's Temporary Plan For The Prevention Of Senchi From Thinking Too Hard' (125); 'You make me feel so unmarried; confusing Senchi's Plan for the Ruination of Women' (134). Senchi's foolishness thus takes a quizzical view of discourses both of colonialism and of postcolonial reconstruction, and as I shall go on to suggest, there is a possible political wisdom in his foolery.

When Senchi goes on to invoke the figure of the madman itself, it is arguably an even more significant moment. Senchi recites a story, partly in verse, which he claims to have heard from a man who was mad, 'or simply stark raving poor' (141). Since Kankam has already said that the mad 'seem to know things hidden from men in their right minds' (111), the madman's words have a claim to authority. Senchi does not make that claim explicitly, and keeps a distance from the story himself, which may be tactical, because the words of the madman criticise several elements of society: (141)

\footnotetext{
[the madman] feels that men must heed his creed; or at the least applaud the wit with which he calls them sons of a bitch. ...

' Gentlemen, show me a thought you've thought through, and I'll bow to you right low and grant you a master's due.
}

'Feather-fine ladies with hips that rhyme, who the blazes minds your children's manners at this time?

'Left, right, left, does not feed a nation. I'd rather have you roaring drunk at a harvest celebration...

If we grant any importance to the last line, the play's only explicit reference to the nation, it could be understood as a critique of the play's wider political context. As I noted earlier, the play was produced in 1962, but by the time of its publication in 1967 many Ghanaians were dissatisfied with Nkrumah's post-independence government; the administration had become 
authoritarian and the economic policies brought few tangible rewards. ${ }^{34}$ The generalised complaints of the 'madman' could be read without any specific political purchase, but the mention of militarism and the nation - and its inadequacies - perhaps points in the direction of a critique. Since the words are repeated from a madman, there is no simple identification between his utterance and the stance of the play overall, but it may be significant that Senchi eventually gets the whole Chorus to sing and dance to his words, all caught up in what may be an expression of dissent (142).

Most readers have not found Edufa to be a critique of Nkrumah's regime, or indeed to have a political focus at all. Inasmuch as the play explores the problem of reconciling traditional elements of the culture with those derived from the European incursions, it has been understood more as an exhortation to Ghanaians generally. Sutherland has been understood as a supporter of Nkrumah who worked closely with him to build the theatrical and cultural institutions of the new nation; any critique in her drama has been understood as cultural, addressed to the morality of the community, rather than political, and this stance has been thought characteristic of Ghanaian dramatists generally. ${ }^{35}$ Sutherland's play Foriwa, produced a few months after $E d u f a$, has, however, been understood in the secondary literature to look askance at Nkrumah's Ghana, suggesting that Ghana stagnates like the village of Foriwa's birth. ${ }^{36}$ This critical viewpoint opens the possibility of reading Edufa in a more interrogative fashion.

Some of Sutherland's pronouncements on the role of the creative artist indicate that she was fully aware of possible conflicts between the political and the cultural spheres. Although she seems to have described art as an indispensable part of social development, she seems also to have been distrustful of the notion of the artist's dependence on government. ${ }^{37}$ Conversely, while sources represent her as fully accepting the role of the artist as a social 
critic, they suggest that she did not endorse political actions that would endanger the art. Of the view articulated at a 1980 conference, that the writer possessed special qualities of insight that obliged him or her to act as a social critic, Robert July writes that 'Efua Sutherland concurred, although she...drew sharp distinctions between effective artistic commentary and political acts that might end in the silencing of an important voice' ${ }^{38}$ To negotiate the demands of an emergent society experimenting with new political and cultural forms might well require from the creative artist the careful tightrope walking that Sutherland's quoted words suggest. ${ }^{39}$ Although some of Sutherland's published words seem to support Nkrumah over and against the regimes that followed, ${ }^{40}$ we do not need to posit her personal disaffection with the administration to suggest that her contemporary dramatic work registered political unease; we may further conclude that one advantage of the culturally valued form of Greek tragedy was that it served to distance any political critique, and to deflect any consequences that might have otherwise followed from the detection of a critical voice. $^{41}$

If we pursue the notion of the play as critique, we might even suggest that the man Edufa is a version of Nkrumah, in that he is held in wide admiration and affection, but is eventually destructive of what loves him and what indeed he loves. Nkrumah was faced, like many other contemporary African leaders, with the task of rebuilding a nation that had suffered systematic exploitation and depopulation, and of integrating what the west could offer with what the indigenous culture could not afford to lose. In miniature, this is the dilemma that confronts Edufa, and the presence of the Greek tragic form, in its altered state, shows us that this is what confronts the playwright too. Sutherland claimed in 1968 that 'nobody has the answer to how to do drama in this society yet', 42 and the play Edufa can be seen as one response to the problem of how to do drama, deploying Greek tragedy to ask pointed questions about the human capacities of the new nation. But to adapt a Greek play in 
the years close to independence is an anomalous choice for any African writer, because it involves acknowledging the cultural power of colonialism at the very moment when African leaders and communities are dedicated, necessarily, to the ideals of self-determination and autonomy. The co-existence of the Greek and Ghanaian elements in the new play multiplies the difficult combination of tragic and comic, healing and grotesquerie, that Sutherland might have read in the Alcestis. So should the process of Afro-Greek adaptation be counted here as wisdom or as folly?

Sutherland's writing was usually circumspect about western influences. ${ }^{43}$ In 1968 she is recorded as emphasising the necessity to develop indigenous literature: 'I would prefer us looking at it and using it [Ghanaian history] to doing imitative art like performing plays just because they exist in books already... They're always there to be used by anybody, but we have a duty to create some'. ${ }^{44}$ In an interview not published until 2007 she said that 'Everybody has been to school with the English tradition of theatre. Shakespeare, Molière...all those things' and concluded that her task as playwright was to offer what was Ghanaian in the sense both of rooted in African tradition and of recognisable to a society marked by colonial culture. ${ }^{45}$ Her example is Odasani, an Everyman play (1961), but Edufa is the product of a similar enterprise, where the contradictory blending of traditions and forms is a self-conscious response to the pressures of postcolonial society.

Despite her commitment to Ghanaian culture, Sutherland's own cultural position was not without complexity in its combination of Ghanaian and western. Educated at a mission school, St Monica's, and at Homerton College, Cambridge, she had a serious acquaintance with classical drama. In the interview previously cited she says of her education: 
they used to put on in Cape Coast an annual Greek tragedy, as a school performance...the staff and students. ${ }^{46}$ My uncle went to that school, which was probably why I got to attend those plays where he performed. And I remember seeing Robert Gardner...yes, as Creon in Antigone, when I was a child, as a young girl. Antigone, Agamemnon...I loved it...I understood what was going on... I read a lot of the Greek tragedies. And when I was teaching at training college, Asante-Mampong, I produced some of these plays myself. I produced the Medea. I produced Antigone, I produced the Alcestis... ${ }^{47}$

Such a background was not untypical for a Ghanaian of her class and period, but would not have been shared with the mass of Ghanaians. In a 1968 interview Sutherland is seemingly conscious of her ambivalent cultural locale: ${ }^{48}$

I'm on a journey of discovery. I'm discovering my own people. I didn't grow up in rural Ghana - I grew up in Cape Coast with a Christian family. It's a fine family, but there are certain hidden areas of Ghanaian life - important areas of Ghanaian life, which I just wasn't in touch with. In the past four or five years I've just made a very concentrated effort to make it untrue that I do not know my people and I know them now.

Sutherland's acculturation into her own culture is represented as a deliberate, one might say a political act. It is of a piece with the work of nation-building consequent on Ghana's independence, which can also be seen to drive her theatrical activity and associated institutional initiatives. Within this context Greek drama becomes potentially very relevant. A persistent western model relates a society's health to the dynamism of its drama, and counts fifth-century Athens as the zenith of both. ${ }^{49}$ To invoke Greek as well as Ghanaian models, then, involves a possible contradiction, because of the ways in which the colonial inheritance undermined the health of the indigenous culture; yet in the project of constructing a new nation via its drama, this contradiction may be soluble. The tragic form itself might reconcile the opposites of traditional and western, deadly charm and pernicious materialism. 
The finale of Edufa, however, resists any such encouragement. Instead, it chooses to close with the figure of the madman, and this time he is not gifted with any special insight. Ampoma dies in the play's final moments, indoors and offstage, with the housekeeper Seguwa denouncing Edufa to the Chorus and Senchi calling at the door of her room to know what is going on. The stage directions then have Edufa come onstage from her room, 'a man clearly going out of his mind' (152). He speaks violently, 'his voice unnatural' (152) and fails to recognise his friend; when Senchi lays hands on him, he looks at him 'dangerously', resists 'with more than natural strength' and then he delivers his final speech (153). An attempt is made to conquer Death and retrieve Ampoma, but not by the Heracles-figure.

\footnotetext{
Where is my leopard skin? I'll teach Death to steal my wives. [So strong that Senchi can no longer restrain him] Death, I will lie closely at the grave again, and when you come gloating with your spoil, I'll grab you, unlock her from your grip and bring her safely home to my bed...[Wrenching himself free] The last laugh will be mine when I bring her home again. I will bring Ampoma back. Forward, to the grave. [He moves in strength towards the back courtyard, roaring.] I will do it. I am conqueror! [His last word, however, comes as a great questioning lament.] Conqueror...?
}

Recognisably referring to the Greek Heracles who wore a lion-skin to perform his feats, and wrestled Death to free Alcestis, the leopard-skin of Edufa also cites the rulers of pre-colonial Africa, who wore the skin as part of official regalia. ${ }^{50}$ Edufa can thus be seen to reach for his African roots, but since he is also channelling the Greek Heracles, he is combining the two traditions in the same way as does the play. But inasmuch as this play ends without a rescue, he can make neither symbol work for him, and indeed he only reaches for the leopard-skin when he is already beyond reason. Whereas the Greek Alcestis allowed a salvation that moved the play, with the return of the inscrutably silent wife, towards the comic or at least satyric end of the dramatic spectrum, the African Alcestis 'corrects' this tendency by being a 
'proper' tragedy and ending before the rescue. Yet to do so it must give up the dramatic power to overcome death, and its silence is no longer ambivalent. The convergence of the Greek and Ghanaian dramas marks a failure rather than a productive encounter, the comedy is subsumed in tragedy, and madness prevails over any possibility of sane adjustment to the constraints of mortal existence.

Alcestis binds together wisdom and folly in the same way as it features both tragic and comic elements, and offers its characters for negative as well as positive judgement. Edufa also extends multiple possibilities of cultural, moral and generic identity. But it chooses in the end to identify with tragic madness and despair, refusing the Greek play's offer of escape from that necessity. In this, I have suggested that the play registers the difficulty of Ghanaian politics during the last few years of Nkrumah's rule. It also undoubtedly responds to the postcolonial situation of mixed and potentially antagonistic cultures, in which the Greek tragedy acts as an artistic resource but also exerts pressure on African creativity. ${ }^{51}$ In this context it struggles to discern where wisdom might lie between tradition and westernisation, and its version of folly turns to a bleak madness.

Bibliography

Adams, Anne V. (2000), "Revis(it)ing Ritual: the challenge to the virility of tradition in works by Efua Sutherland and other African writers", in: Matatu 21-22: 85-94

Adams, Anne V. and Esi Sutherland-Addy (eds.), The Legacy of Efua Sutherland: panAfrican cultural activism, Banbury

Ahl, Fred (1997), “Admetus Deuteragonistes”, in: Colby Quarterly 23:1, 9-25

Amissah, G. McClean (1980), Reminiscences of Adisadel, Accra 
Ankumah, Adaku T. (1998), "Efua Theodora Sutherland (1924-1996)” in: Pushpa Naidu Parekh and Siga Fatima Jagne (ed), Postcolonial African Writers, Westport CT, 455-59 Banham, Martin (ed.), (2004), A History of Theatre in Africa, Cambridge Banham, Martin, Erroll Hill and George Woodyard (1994), The Cambridge Guide to African and Caribbean Theatre, Cambridge

Branch, William B. (2007), “Efua Theodora Sutherland: A Personal Reflection”, in: Adams and Sutherland-Addy (eds.), 219-220

Budelmann, Felix (2005), "Greek tragedies in West African adaptations”, in: Goff (ed.), $118-46$.

Busby, M. (2007), "Introducing Daughters of Africa", in: Adams and Sutherland-Addy (eds.), 131-149

Duerden , Dennis and Cosmo Pieterse (1972), African Writers Talking, London Gocking, Roger S. (2005), The History of Ghana, Westport CN

Goff, Barbara (2013), Your Secret Language: classics in the British colonies of West Africa, London

Goff, Barbara and Michael Simpson (2007), Crossroads in the Black Aegean: Oedipus, Antigone, and dramas of the African diaspora, Oxford Greenwood, Emily (2010), Afro-Greeks: dialogues between Anglophone Caribbean Literature and Classics in the Twentieth Century, Oxford Hardwick, Lorna (2003), Reception Studies, Oxford Hardwick, Lorna (2007), "Contests and Continuities in Classical Traditions: African Migrations", in: John Hilton and Anne Gosling (eds.), Alma Parens Originalis? The Receptions of Classical Literature and Thought in Africa, Europe, the United States and Cuba, Bern, 43-72. 
Jeyifo, Biodun (2007), "When Anansegoro Begins to Grow: reading Efua Sutherland three decades on", in: Adams and Sutherland-Addy (eds.), 24-38

July, Robert (1987), An African Voice: the role of the humanities in African independence, Durham NC

July, Robert (2007) “"Here, then, is Efua': Sutherland and the Drama Studio”, in: Adams and Sutherland-Addy (eds.), 160-164

Lodge, Tom (2006), Mandela: a critical life, Oxford

Martini, J. (2007), “Meshack Asare: 94-103

Mbembe, Achille (1988), Afriques indociles: Christianisme, pouvoir et Etat en société postcoloniale, Paris

Nietzsche, F. (1956), The Birth of Tragedy and the Genealogy of Morals, New York Okafor, Chinyere (1980), "Parallelism versus Influence in African Literature: The Case of Efua Sutherland's Edufa", in: Kiabara: Journal of the Humanities 3 (1), 113-131.

Osofisan, Femi. 2007. “"There's a lot of Strength in Our People': Efua Sutherland's Last Interview", in: Adams and Sutherland-Addy (eds.), 200-210

Owusu, Heike (2000), Symbols of Africa, New York

Owusu, Martin (1983), Drama of the Gods: a study of seven African plays, Roxbury Padilla, Mark (2000), "Gifts of Humiliation: Charis and Tragic Experience in Alcestis", in: AJP 121. 2, 179-211

Parker, L.P.E. (2007), Euripides Alcestis: with introduction and commentary, Oxford Pearce, Adetokunbo (1987), “The Didactic Essence of Efua Sutherland's Plays”, in: African Literature Today $15,71-81$

Peek, Philip M. and Kwesi Yankah (2004), African folklore: an encyclopedia, London 
Reiss, Timothy (2009), “Using Tragedy against its Makers: some African and Caribbean instances", in: 508- 537 Rebecca Bushnell (ed.), A Companion to Tragedy, Malden MA, $508-37$

Reiman, Donald (1977), Shelley's Poetry and Prose, New York

Rotimi, O. (2007.), “The Attainment of Discovery: Efua Sutherland and the Evolution of Modern African Drama”, in: Adams and Sutherland-Addy (eds.), 18-23

Rutherford, R. (2012), Greek Tragic Style: form, language, interpretation, Cambridge Segal, Charles (1993), Euripides and the Poetics of Sorrow: art, gender and commemoration in Alcestis, Hippolytos and Heracles, Durham NC and London

Seidensticker, Bernd (2008), "Dithyramb, Comedy, and Satyr-Play", in: Justina Gregory (ed.), A Companion to Greek Tragedy, Oxford, 38-54

Snell, Bruno (1924), Die Ausdrücke für den Begriff des Wissens in der vorplatonischen Philosophie, Berlin.

Steegstra, Marijke (2004), Resilient Rituals, Münster

Stieber, Mary (1998), "Statuary in Euripides' Alcestis"”, in: Arion 5, 69-97

Steiber, Mary (2011), Euripides and the Language of Craft, Leiden

Sutherland, Efua T. (1987), The marriage of Anansewa; Edufa : two plays, Harlow

Sutherland-Addy, Esi ( 2006), "Creating For and With Children in Ghana”, in: Michael Etherton, Martin Banham and Jane Plastow (eds.), African Theatre: Youth, London, 1-15 Talbert, Linda Lee (1980), “Alcestis and Edufa: The Transitional Individual”, in: World Literature Written in English 22, 183-90

Van Weyenberg, Astrid (2013), The Politics of Adaptation: Contemporary African Drama and Greek Tragedy, Amsterdam

Wetmore, Kevin J. (2002), The Athenian Sun in an African Sky, Jefferson, NC Wetmore, Kevin J. (2003), Black Dionysos, Jefferson, NC 


\section{Wilentz, Gay (1992a), Binding Cultures: black women writers in Africa and the diaspora, Bloomington and Indianapolis}

Wilentz, Gay (1992b), "Towards a diaspora literature: black women writers from Africa, the Caribbean, and the United States", in: College English 4.4, 385-405

\footnotetext{
$1 \quad$ Rutherford 2012, 380-81.

2 On the genre of Alcestis see e.g. Seidensticker 2008, 50-51. Hypothesis B suggests that the drama is 'more satyric' ( $\sigma \alpha \tau \nu \rho \kappa \omega ́ \tau \varepsilon \rho o v)$, and commentators have continued to debate the possible implications of this.
} Even without the hypothesis, however, it is likely that notice would have been taken of the play's multiple generic affiliations.

3 Padilla 2000, 179 has an historical conspectus of views of the play in general.

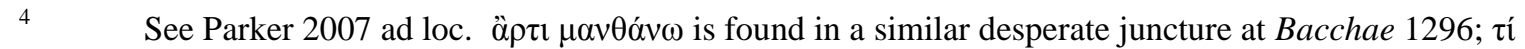

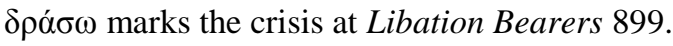

5 Okafor 1980 disputes the notion that Edufa invokes Alcestis, and suggests instead the Ashanti legend of the self-sacrificing Tweneboa Kodua. Most critics agree that Alcestis is also relevant. Okafor's overall discussion of the differences between Alcestis and Edufa is important.

$6 \quad$ Origa $2007,14$.

$7 \quad$ My translation, more or less literal in order to convey how strange the sentiment may appear.

8 Segal 1993, 39 suggests that drama itself defeats death, but only by providing a simulacrum of life in art, myth or fantasy, as this play defeats death by providing a silent version of Alcestis.

$9 \quad$ Steiber $2011,415$.

10 Parker 2007 ad loc calls Admetus' project 'disconcerting', 'extravagant' and 'bizarre', to the original audience as well as to us. See e.g. Ahl 1997, 12 on various views of this moment and of Admetus overall.

$11 \quad$ See also Steiber 1998.

$12 \quad$ Origa $2007,66$.

13 See Parker 2007 ad loc on the paradoxical and 'mixed' nature of their utterance here. Origa 2007, 108 notes how the Chorus connects sophia with eugeneia, aidos, and theosebeia. 
14 Meridier and Murray punctuate after бopías.

Parker 2007 ad loc terms it 'startling, but not at all unorthodox. Greeks had difficulty in seeing any rational justification for acts of pure self-sacrifice'.

16 See Parker 2007, li-lv for discussion of key readings.

17 See especially Wetmore 2002, Budelmann 2005, Hardwick 2007, Goff and Simpson 2007, van Weyenberg 2013.

18 On the term see Wetmore 2002:3. Greenwood 2010, 7 suggests that it may originate in the work of Derek Walcott.

19 Only John Pepper Clark-Bekerdemo's Song of a Goat, which is not always included in this group, is earlier (1961).

20 Among the institutions she founded were the magazine Okyeame, the publishing house Afram Publications, the Ghana Society of Writers, the Ghana Drama Studio, which was the forerunner of the National Theatre, and the Kodzidan or Story House in Atwia, which promulgated traditional performance techniques. For accounts of this work see e.g. Adams and Sutherland-Addy 2007.

21 Compare the African adaptations Demea by Guy Butler, a version of Medea, The Bacchae of Euripides: a communion rite by Wole Soyinka, and Tegonni: an African Antigone by Femi Osofisan. 22 See e.g. Pearce 1987, 71, Wilentz 1992a, 21, Adams 2000, 86-7. Edufa in particular has sometimes been evaluated quite negatively for awkward language and improbabilities of plot; see Pearce 1987, 80, Wetmore 2002, 129, and Rotimi 2007, 20.

23 For instance Reiss 2009, which shares some of my conclusions although not many details of my analysis.

$24 \quad$ All quotations are taken from Sutherland 1987.

25 On the community dimension of Ghanaian drama, see Banham ed. 2004, 38-40, Wetmore 2002, 50-51.

$26 \quad$ See e.g. Wetmore 2002, 129.

27 This is the case with Foriwa, on which see especially Wilentz 1992a and b, and Ankumah 1998. In The Marriage of Anansewa the hero, or rather antihero, is a westernised man driven by greed.

28 Nyame is the Supreme God; ntoro is the psychical inheritance from the father which (along with the inheritance from the mother) helps to make up the child.

29 Wetmore 2002, 122 and Jeyifo 2007, 32 argue that she is less important than Alcestis.

$30 \quad$ Peek and Yankah 2004, 24. 
2009, 524 claims that Ampoma enacts an elaborate and 'embarrassingly' public ceremony to shame Edufa into keeping his vow not to remarry.

32 See Jeyifo 2007, 31 on Sutherland's 'subtle and deliberately understated critique of the patriarchal domination of women' in this play.

See e.g. Talbert 1983, 189, Wetmore 2002, 128, Reiss 2009, 523-3.

See on the state of Ghana in this period Gocking 2005, 131-39.

See Banham, Hill and Woodyard 1994, 38 Wetmore 2002, 120

Ankumah 1998, 456

Duerden and Pieterse 1972, 192-33.

July 1987, 230. See also Busby 2007, 222.

Sutherland-Addy 2006, 14 points to the complex and thoughtful endings of Sutherland's plays for children, claiming explicitly that they are not simply 'moralistic'.

See e.g. Osofisan 2007, 204, and Martini 2007, 103.

Hardwick 2003, 109 makes this case for other adaptations.

Duerden and Pieterse 1972, 191.

Sutherland herself chose Edufa by for inclusion in the 1993 anthology Crosswinds: an anthology of

Black dramatists in the diaspora (Bloomington: Indiana University Press), as detailed in Branch 2007, 220.

$44 \quad$ Duerden and Pieterse 1972, 188.

45 July 2007,163

46 This school is Adisadel College, which maintained a strong classical focus until the 1960s. See Amissah 1980, Goff 2013.

$47 \quad$ July $2007,160$.

$48 \quad$ Duerden and Pieterse 1972, 189

49 Shelley, Hegel and Nietzsche all contribute to this view; see Shelley's 'A Defence of Poetry' in Reiman 1977, 488-89; Chapter 21 of Nietzsche's Birth of Tragedy.

50 See Owusu 2000, 39. Nelson Mandela wore a leopard-skin at his trial (Lodge 2006, 189), but in other contexts, such signs of traditional African authority may be considered corrupted by their adoption on the part of neo-colonial autocrats such as Mobutu Sese Seko of Zaire. See Mbembe 2001, 129-30. 
'Edufa was written when early hopes of cultural recovery and political sovereignty in Ghana were fading, when hopes of mutual enriching of cultures were being devoured by realities that look more like a ruin of values....' 